\title{
Translation Strategies of Islamic Terms In Indonesian-English Research Papers
}

\author{
Muhammad Farkhan \\ English Literatures Department Syarif Hidayatullah \\ State Islamic University Jakarta, Indonesia \\ farkhan@uinjkt.ac.id
}

\begin{abstract}
The study examined whether strategies employed in translating Islamic terms of the research papers from Indonesian into English distorted the intended messages. Translation strategies refer to ways of transferring messages or meaning from a source language (SL) into a target language (TL). The data of the study were Islamic terms of dissertation abstracts representing different themes taken randomly from the university repository. All data were qualitatively analyzed using the concepts of translation strategies relevant to the dissertation's abstracts as research papers. The study showed translators mostly used preservation, addition, globalization, and localization strategy. Preservation strategy is used by borrowing the source language terms for there was difficult to find the same terms in English as TL; and an addition strategy by using English terms with brief descriptive notes placed in the text. Globalization utilized TL generic words because they conveyed meaning commonly understood by readers; and localization employed deleting, changing, and adapting SL words' phonological components and graphic symbols. The analysis also indicated that the translation of Islamic terms of dissertation abstracts from Indonesian into English was dominantly influenced by foreignization-ideology. This led to produce certain meaning distortion in the TL that made readers misunderstand the intended messages.
\end{abstract}

Keywords---Islamic terms; translation strategies; source language; target language

\section{INTRODUCTION}

Currently the writing of research papers spread widely among lecturers and students in the universities as the main requirement to accomplish to the higher degree or promotion of new job [1]. In Indonesia, for example, writing a research paper published in indexed international journal becomes one of requirements to deserve higher academic ranks, e.g. associate professor to professor [2]. The issue of the ministry decree implies intensive and continuous efforts aimed at building the academic culture and atmosphere to increase the quality and quantity of academic articles [3], including research papers talking about various disciplines, such as politics, education, psychology, linguistics, or religion.

Each discipline has its own words or jargons, such as Islamic terms, that are usually difficult to write in English. They originate from "Islam" as a religion and the local cultures where
Muslims practiced and acculturated [4]. They resemble mostly in research papers written by Muslim scholars who want to convey the Islamic messages of peace, gender equals, education, and other values to the world [5]. Therefore, writers have to choose right English words that are equal to Islamic terms in meaning that readers will be able to get the same linguistic nuances [6]. Nevertheless, they sometimes get difficulties finding the appropriate words by translating from Quranic, Arabic or Indonesian words into English. Such difficulties lie on the different concept because of cultural background and points of view, which have to be taken into consideration.

To find out the appropriate English words, the writers should use accurate translation strategies in order that the English words they utilize are equivalent to the originals. Translation strategies refer to procedures or techniques used in identifying the TL words having similar meaning by adopting or adapting the SL words, creating new words (neologism), or using the target language words [7]. Of course, to find the equivalence, the writers also have to consider linguistic and cultural components, which usually help shape the intended meaning. The linguistic components to think are, for example, whether the translated words need any phonological or graphical adjustment to ease the target language readers to pronounce or to write; or morphological changes that deal with the meaning [8]. However, the writers have not utilized translation strategies optimally as there are still problems or difficulties in understanding the intended meaning of the words used in the target language. This triggers my curiosity to conduct a research to explore more about the translation strategies used in transferring the meaning or message of Islamic Terms from Indonesian or Arabic language as the source language to English as the target language. Whether the translation strategies are effectively used in transferring the meaning from the source language into the target language without any distortion is still interesting to study.

There are studies about translation strategies, but about translating Islamic Terms, there are still rarely to find. A study concerning with strategies in translating cultural terms from English into Arabic indicates that translators did not focus on using one strategy, but combined two or more strategies to 
arrive at the natural translation product [9]. This means that translators cannot rely on one strategy, but have to mix more strategies in accordance to the lexical and syntactical elements of the text. However, this study does not explore more about the transfer of cultural words, especially Islamic terms. Therefore, this is a challenging opportunity to conduct a study on translation strategies of the Islamic terms in the dissertation abstracts as research papers.

Bolling in 2016 has also done a research with a different focus. His study investigated about the translation of the cultural words in literary works. It found out that some translators got difficulties in searching the accurate words in the target language for the terms in the source language [10]. They tended to leave certain cultural words untranslated because they want that readers of the target language not to lose special experience with the story. Of course, this study leaves more debates on how to translate cultural words, which refer to specific domains of the cultural heritages of the source language. This also encourages me to conduct a new study on the translation of Islamic terms, which can be assumed as one of the cultural specifics of heritages.

Differently from the previous studies, El-Zeiny in his article shows that lexical gaps caused problems in translating Islamic terms into English; and recommends using lexicographic approaches to bridging such gaps by comparing three dictionaries to find equivalences of Islamic terms in Arabic and English [11]. However, the study does not focus on Islamic terms appearing frequently in research papers. It implies that study on translating Islamic terms from Arabic or Indonesia as a source language into English as a target language is necessarily to conduct.

Referred to the previous studies, the article examined whether strategies employed in translating Islamic terms of the dissertation abstracts from Indonesian into English distorted the intended messages of the target language terms. More specifically, the study tries to identify which strategy among preservation, addition, omission, globalization, localization, transformation, and creation the translators used dominantly. were dominant translation strategies. In addition, it also focuses on the translation ideology that the translators held in transferring the meaning from the source language to the target language.

\section{METHOD}

The study of course counted on the verbal data of Islamic terms in 48 dissertation abstracts taken randomly from UIN Jakarta repository. They discussed Islam from different perspectives, like Sufism, jurisprudence, $d a$ 'wah, Islamic bank and finance, education, philanthropy, politics, and emancipation. All data were qualitatively analyzed using the concepts of translation strategies relevant to the dissertation abstracts as research papers by comparing Indonesian and English version. In addition, the analysis of the data makes use also the translation ideology of foreignization and domestication to see the quality of the English version as targeted language.

\section{RESULT AND DISCUSSION}

Translation strategies can be defined as potentially conscious procedure for the solution of a problem, which an individual faced when translating a text segment from one language to another. They can be both the conscious and unconscious procedures; and both overt tactics and mental processes that consist of identifying and creating multiple relationships in both cultural association and language at the semantic and phonological levels [12]. Armed with this concept of translation strategy, I was eager to conduct a study involving abstracts written by doctoral program graduates of the postgraduate school of UIN Jakarta. The abstracts comprised of 13 fields of study, namely language and literature, Sufism, Islamic Jurisprudence, economy and business, history, politics, etc. Among of these fields, Islamic jurisprudence and education fields are the most frequently discussed topics. Descriptively, the analyzed data resemble in Table 1 distributed in accordance with the translation strategies and the fields of study.

TABLE 1

TransLation StrategIES ADOPTED By THE WrITERS

\begin{tabular}{|l|c|c|c|c|c|c|c|}
\hline \multirow{2}{*}{\multicolumn{1}{|c|}{ Field }} & \multicolumn{7}{|c|}{ Translation Strategies } \\
\cline { 2 - 9 } & P & A & O & G & L & T & C \\
\hline $\begin{array}{l}\text { Language and } \\
\text { Literature }\end{array}$ & 64 & 2 & 0 & 0 & 17 & 0 & 0 \\
\hline Dakwah & 34 & 0 & 0 & 0 & 0 & 0 & 0 \\
\hline $\begin{array}{l}\text { Economy and } \\
\text { Business }\end{array}$ & 32 & 3 & 0 & 0 & 1 & 0 & 0 \\
\hline $\begin{array}{l}\text { Islamic } \\
\text { Jurisprudence }\end{array}$ & 149 & 13 & 0 & 0 & 2 & 0 & 0 \\
\hline Law & 119 & 15 & 0 & 0 & 0 & 0 & 0 \\
\hline Thoughts & 29 & 6 & 0 & 4 & 0 & 0 & 0 \\
\hline Education & 49 & 2 & 0 & 0 & 0 & 0 & 0 \\
\hline $\begin{array}{l}\text { Banking and } \\
\text { Finance }\end{array}$ & 32 & 3 & 0 & 1 & 3 & 0 & 0 \\
\hline Politics & 22 & 1 & 0 & 0 & 2 & 0 & 0 \\
\hline History & 28 & 0 & 0 & 0 & 0 & 0 & 0 \\
\hline Hermeneutics & 74 & 4 & 0 & 0 & 1 & 0 & 0 \\
\hline Sufism & 127 & 6 & 0 & 0 & 1 & 0 & 0 \\
\hline Miscellaneous & 70 & 7 & 0 & 0 & 0 & 0 & 0 \\
\hline $\begin{array}{l}\text { TOTAL } \\
\text { Tote: }\end{array}$ & $\mathbf{8 2 9}$ & $\mathbf{6 2}$ & $\mathbf{0}$ & $\mathbf{5}$ & $\mathbf{2 7}$ & $\mathbf{0}$ & $\mathbf{0}$ \\
\hline $\begin{array}{l}\text { P: Preservation } \\
\text { L: Localization }\end{array}$ & T: Transformation & C: Creation & \\
\hline
\end{tabular}

Table 1 briefly shows there are four strategies utilized by the abstracts writers, namely preservation (90\%), addition (7\%), globalization (1\%), and localization (3\%); and three other translation strategies were not used. Those strategies are used in transferring the meaning of Islamic terms from Indonesian into English because of the cultural contents or elements of the source language, not because of its linguistic contents. To understand more comprehensively, why the writers employed 
such strategies would be elaborated successively from preservation, addition, globalization, and localization.

Preservation becomes the most frequently used strategy in translating the Islamic terms from Indonesian into English. It is mostly done by maintaining the original form of the SL [13], and it is also related to the preservation of meaning across two different lingua-cultures [14]. The use of preservation indicates that the terms translated do not refer to the concepts of Islamic teaching and other cultural contents. They mostly denote to references existing in the world, such as the name of persons, places, days, and the title of the book. The words like $A L$ Ghazali, Ahmad Dahlan, Tafsir Ibnu Katsir, Makkah AlMukarramah, and Al-Madinah Al-Munawwarah appear in English abstracts. They are not transliterated into English to maintain their cultural elements so that TL readers can experience the same as well as SL readers. Therefore, preservation is assumed to be accurately used if SL words are references. However, there are also some Islamic terms referring to concept of worship are also kept untranslated, for example, fiqh, tauhid, and taqwa. Fiqh means all principles or rules of worship; tauhid means the concept of believing in one God; and taqwa means surrendering oneself to Allah almighty and accepting His destiny.

Addition is the second popular strategy utilized by the abstract writers, although it only reached $7 \%$ of the total terms found. Addition refers to any supplementary information attached to the translated terms in order that SL readers are able to catch the intended message. Additional information in the translation may take various forms: (1) within the text, (2) notes at bottom of page, (3) notes at end of chapter, and (4) notes or glossary at end of the book [15]. In short, I can say the translators may decide to keep the original item but supplement the text with whatever information is judged necessary [16]. Different from preservation, addition can be used in translating all cultural items including Islamic terms with any description or information considered important to add. The Islamic terms that denote any references can be maintained in the TL with any brief information. For example, the translators can keep $A l$ Munjid in English as Al-Munjid (a monolingual Arabic dictionary and thesaurus). Here are Islamic terms with their brief description in the brackets: ibadah (men's relationship to Allah), munakahat (principles and guidance of marriage), muamalat (men's relationship to other in economy and other social fields) and jinayat siyasah (criminal laws). Contradictorily to addition is omission by deleting word from the TL words [17]. It will be possible to use if the SL is the level of phrase, clause, or sentence as long as the meaning to convey is not distorted [18]. However, in the level of words or terms, the strategy is difficult to use because they will lose their meaning and change their graphical symbols [19].

Globalization strategy refers to translation strategy using more common TL terms (usually connected with TL terms) to make it globally used or accepted [20]. From the available data, the abstract writers do not use this strategy frequently as there are less terms necessarily to be translated using this strategy. Some terms, like Sunnah rasul, paham tauhid, perbankan syariah, and ibadah haji are found to be appropriately translated into English using this strategy. The term Sunnah rasul is changed to prophet's tradition; paham tauhid to Islamic monotheism; perbankan syariah to Islamic bank; and ibadah haji to Islamic pilgrimage, which are commonly and globally understood by the TL readers. Therefore, globalization makes the SL word global or known globally [21], [22], [23]. In this study, the abstract writers adopted globalization strategy in translating the Islamic terms considered to spread globally as they are more common among the TL readers.

The last strategy the abstract writers also use is localization by adapting SL terms' phonemes or graphical symbols to help the TL readers easily be familiar with them [24]. There are few terms found to be translated using this strategy, such as Abasiah, chalifah, Kufah, Umayyah, and Syariah. In translating those terms, the writers make phonological adaptation to conform to the TL system. They become Abasid, caliph, kufa, Ummayad and sharia. It can be said that localization involves all changes to all levels of text to help the TL readers that come from other languages and cultures can understand the translated text properly [25]. Therefore, the SL terms will be differently adapted in accordance with the TL system of phoneme or morpheme.

Another two strategies, transformation and creation, do not appear in the abstract translation. Transformation refers to cases where the modification of the SL terms seems to go beyond globalization or localization, and could be seen as an alteration or distortion of the original [26]. This means that SL words are translated into TL words, which are different in cultural usage. Romeo and Juliet, for example, is replaced in Indonesian by Rojali and Julaekah. Creation means making new terms in target language, which is also known as neologism [27]. If the TL does find any strategies that accommodate the process of translation, creation will become an alternative solution.

Essentially, all strategies above can be differentiated into two main ideologies of translation: domestication and foreignization [28]. Domestication encompasses changing the source language and culture to ensure it closely conforms to the target language and culture being translated into, which often leads to a loss of information, message nuance or emotional impact from the original source material. It is used to minimize the strangeness of the SL conceptualization for the TL readership [29]. Foreignization, on the other hand, comprises maintaining in these foreign features from the source text in order to retain its meaning, even though this act requires purposely breaking the conventions of the target language [30]. It refers to those aspects of a translated work that retain elements of the source language in such a way as to remind readers of target language [31]. In contrast, a domesticated translation removes and hides aspects of cultural difference so that readers can absorb the information or story from within their own familiar cultural framework. The study reveals that foreignization is highlighted through the heavy usage of preservation and addition in translating the Islamic terms from Indonesian into English. 


\section{IV.CONCLUSION}

Having discussed the result, I am able to propose conclusions as follows:

a) The dominant strategies used by the abstract writers are preservation by maintaining the Indonesian Islamic terms in English abstracts; and addition by keeping the Indonesian Islamic terms attached with brief description;

b) As the adopted strategies maintained the features of the source language, they are foreignized-ideology;

c) The translators can choose the appropriate translation strategies by taking into consideration the linguistic and cultural element of the SL as well as TL.

\section{REFERENCES}

[1] D. Zartner, K. Carpenter, G. Gokcek, M. Melin, and C. Shaw, "Knowledge, skills, and preparing for the future: best practices to educate international studies majors for life after college," International Studies Perspectives, p. ekx004, April, 2017.

[2] The Ministry of Research, Technology, and Higher Education, The Ministry Decree No. 20 on Allowance for Lecturer's Certification and Professorship Honor, Jakarta: --, 2017.

[3] T. Abbas, and A. Zalta, "You cannot talk about academic freedom in such an oppressive environment: perceptions of the We Will Not Be a Party to This Crime! petition signatories," Turkish Studies, vol. 18, no. 4, pp. 1-20, Oct 2017.

[4] S. Shah, Education, Leadership and Islam: Theories, Discourses and Practices from an Islamic Perspective. New York: Routledge, 2016.

[5] S. A. Crabtree, F. Husain and B. Spalek, Islam and Social Work: Culturally Sensitive Practice in a Diverse World. Bristol: Policy Press, 2016.

[6] C. Barbato, "Redefining gender roles: developing relationships between sacred texts and feminism," Master thesis, Department of Theology. Uppsala University, Uppsala, 2017.

[7] J. Dordevic, "Translation techniques revisited: the applicability of existing solutions in non-literary translation," Facta Universitatis, Series: Linguistics and Literature, vol. 15, no. 1, pp. 035-047, Sep 2017.

[8] K.A. Aubakirova, "Nurturing and testing translation competence for texttranslating," International Journal of Environmental and Science Education, vol. 11, no. 11, pp. 4639-4649, 2016

[9] S.M.S. Al-Rushaidi, and H.I.H. Ali, "Translating food menus from English into Arabic: linguistic and cultural dilemmas," AWEJ for Translation and Literary Studies, vol. 1, no. 1, pp. 201-212, Mar 2017.

[10] B. Bollig, "Recent English translations of poetry from Argentina: Contexts and strategies," Translation and literature, vol. 25, no. 1, pp. 107-130. Mar 2016.

[11] I.T. El-Zeiny, "Lexicographic approaches to bridging the lexical gap in translating Islamic juristic terms/concepts into English," International Journal of Lexicography, vol. 30, no. 2, pp. 187-224, Jun 2017.

[12] K. K. Gurdial Singh, "The translation strategies and approaches used by translators of scientific texts from English to Malay," Journal of Modern Languages, vol. 15, no. 1. pp. 221-235, Jul 2017.

[13] J. Boase-Beier, Stylistic Approaches to Translation. New York: Routledge, 2014.

[14] J. House, "Translation quality assessment: past and present," in Translation: A Multidisciplinary Approach, J. House, Ed. London: Palgrave Macmillan UK, 2014, pp. 241-264.

[15] F.D. Sharif, and E. Salimi, "An investigation of the applied strategies in translation of Quranic lexical collocations (Surahs 10 to 20) of the Holy Quran with antonym relationship," Nova Journal of Arabic Studies, vol. 4, no. 1, Mar 2017.

[16] F. Öztemel, and M. Kurt, "Transmission of cultural specific items into English translation of dear shameless death by Latife Tekin," Online Submission, vol. 5, no. 1, pp. 302-320, Apr 2017.

[17] R. K. Kargozari, M. Azarnoosh, and V. Valipour, "Comparing the strategies applied in the translation of culture specific items," Modern Journal of Language Teaching Methods, vol. 7, no. 3, pp. 216-224, Mar 2017.
[18] B. Sadeghi, and A. Farjad, "Translation strategies of English idioms by EFL learners: Baker's model in focus," Language Learning and Applied Linguistic World, vol. 6, no. 3, pp. 247-259, Jul 2014.

[19] R. A. Torghabeh, N. Rahmani, M, Askarpour, and B.A. Branch, "The study of translation strategies of English idioms in children's," The Iranian EFL Journal, vol. 10, no. 2, pp. 153-161, Apr 2014.

[20] J. Munday, Introducing Translation Studies: Theories and Applications. New York: Routledge, 2016.

[21] B. Mousten, "Text travel in the global age," HERMES-Journal of Language and Communication in Business, vol. 19, no. 36, pp. 197217, Mar 2017.

[22] B. Esselink, "Localisation and translation," in Computers and Translation: a Translator's Guide, H. Somers, Ed. Amsterdam: John Benjamins Publishing, 2003, pp. 67-86.

[23] A. Pym, The Moving Text: Localization, Translation, and Distribution, Amsterdam: John Benjamins Publishing, 2004.

[24] J. Torres del Rey, and S. Rodríguez Vázquez, "New insights into translation-oriented, technology-intensive localiser education: accessibility as an opportunity," in The Fourth International Conference on Technological Ecosystems for Enhancing Multiculturality, Salamanca, 2017, pp. 971-978.

[25] N. R. Dongoran, and R. Rakasiwi, "Foreignization and domestication ideological strategies in the translation of the lion, the witch, and the wardrobe into sang singa, sang penyihir, dan lemari," International Journal of Language Learning and Applied Linguistics World, vol. 15, no. 1, pp. 49-57, May 2017.

[26] D. Blažytė, and V. Liubinienè, "Culture-specific items (csi) and their translation strategies in Martin Lindstrom's brand sense," Studies About Languages, vol. 13, no 29, pp. 42-57, 2016.

[27] R. Awang, and G. Salman, "Translation and Arabicization methods of English scientific and technical terms into Arabic," AWEJ for Translation \& Literary Studies, vol. 1, no. 2, pp. 92-106, May 2017.

[28] K. Klaudy, "Linguistic and cultural asymmetry in translation from and into minor languages," Cadernos de Literatura em Tradução, vol. 5, no. 17, pp. 22-37, May 2017.

[29] E. Bagheridoust, and Z. M. Mahabad, "Translation of culture specific items: a case study of Persian architecture terminology," International Journal of Applied Linguistics and English Literature, vol. 6, no. 2, pp. 46-55. Jan 2017.

[30] M. Watson, "Translation studies: shifts in domestication and foreignisation in translating Japanese manga and anime (part one). Bulletin of Kagoshima Junjutsu Junior College, vol. no. 47, pp. 129137, 2017.

[31] E. S. Obeidat, and A.R.H. Abu-Melhim, "Foreignization and domestication in translating English-Arabic baby formula labels," British Journal of Humanities and Social Sciences, vol. 17, no. 2, pp. 50-66, Sep 2017. 